\title{
Date Wastes as Substrate for the Production of $\alpha$-Amylase and Invertase
}

\author{
Acourene Said ${ }^{1^{*}}$, Amourache Leila ${ }^{2}$, Djafri kaouther ${ }^{1}$, Bekal Sadia ${ }^{3}$ \\ ${ }^{1}$ National Institute of Agricultural Research, Touggourt BP 17, Ouargla 30200 ALGERIA \\ ${ }^{2}$ Institute of Nutrition, Food and Agro-Alimentary, Technologies University of Constantine, ALGERIA \\ ${ }^{3}$ Southern Illinois University Carbondale, U.S.A. \\ ${ }^{*}$ Corresponding Author: Acourene Said, National Institute of Agricultural Research, Touggourt BP 17, Ouargla 30200 ALGERIA, P.O. Box: 30200. Tel: \\ +213-777800345, Fax: +213-29693288, E-mail: acourmam@yahoo.fr
}

Received: June 04, 2013; Revised: May 28, 2014

Background: In Algeria the date wastes production is estimated at least 85.000 tones. Date wastes is an economic source
of carbohydrates for conversion to industrial enzymes because it is readily available and relatively low priced.
Objective: The aim of the present study was to investigate the potential of using date wastes as a substrate for the produc-
tion of $\alpha$-amylase and invertase.
Materials and Methods: Thirty strains of $A$. niger were isolated from the saline soils collected from five arid locations in
Algeria. The process parameters; time, temperature, sugar content, initial pH, nitrogen source, nitrogen and phosphorus
content, in the production of these enzymes were optimized.
Results: The obtained results showed the potential of the Aspergillus niger for level productions of these enzymes. For $\alpha$ -
amylase production, the cumulative effect of fermentation period of 96 h, temperature of $30^{\circ} \mathrm{C}$, sugar content of $20 \mathrm{~g} / \mathrm{L}$, ini-
tial pH 5.5, supplemented with yeast extract as nitrogen source, and yeast extract and potassium phosphate at $5.0 \mathrm{~g} / \mathrm{L}$, con-
tent during the fermentation process of date wastes syrup produced $\alpha$-amylase levels up to $285.6 \mathrm{U} / \mathrm{ml}$. Invertase was pro-
duced up to $195.56 \mathrm{U} / \mathrm{ml}$ were produced under optimum conditions of $96 \mathrm{~h}$, temperature of $30^{\circ} \mathrm{C}$, initial pH 6.0 , sugars con-
tent of $40.0 \mathrm{~g} / \mathrm{L}$ and the utilization of yeast extract and potassium phosphate at concentrations of 11.0 and $3.5 \mathrm{~g} / \mathrm{L}$, respec-
tively.
Conclusions: The results obtained, provided evidences, supporting the potential of date waste as suitable source for pro-
duction of $\alpha$-amylase and invertase at industrial scale.
Keywords: Amylase; Date wastes; Invertase; Optimization; Submerged fermentation

\section{Background}

In Algeria, the production of dates is estimated to be 520.00 tons of which 85.000 to 105.000 tons are of low commercial value (1). Date wastes is considered as an economical source of carbohydrates for conversion to industrial enzymes because it is readily available and relatively low priced.

Several extra cellular enzymes are commercially available and widely used in the industry. Among them, $\alpha$-amylases and invertases are used in many industrial processes. For example, $\alpha$ amylases are involved in the assimilation of starch-based matter provided as substrates. Amylases find potential application in a number of industrial processes such as food processing, fermentation, textile, paper industries, and in biotechnology (2). These enzymes are produced by a variety of micro-organisms such as Aspergillus niger, A. awamori, A. oryzae, A. tamarii, Bacillus subtilis, B. licheniformis, Rhizopus oryzae, Candida guilliermondii and Thermomyces lanuginosus (2-7).

Among them A. niger, B. subtilis and R. oryzae are the most applied species in industry $(2,4-5)$.

Likewise, invertase is one of the most important commercial enzymes used in the food industry. It catalyzes the hydrolysis of sucrose in an equimolar mixture of glucose and fructose, known as sugar invert (8). Invertase can be produced by various microorganisms, among them, $S$. cerevisiae, C. guilliermondii, $T$. lanuginosus, $A$. niger, $A$. flavus, A. japonicus, A. ochraceus, Penicillium chrisogenum and $B$. macerans are considered as suitable producers of invertases (9-16).

For industrial production of these enzymes, it is imperative to find inexpensive inducers among the non-conventional substrates. The biosynthesis of these enzymes from energy crops, municipal solid wastes, agricultural and forest residues, or 
other forms of lignocellulosic biomass could improve the economy of $\alpha$-amylase and invertase production $(2,8)$.

The aim of the present study was to investigate the potential of using date wastes as a substrate for the production of $\alpha$-amylase and invertase using A. niger strain ANSS-B5, which was isolated from saline soil areas of the Algerian sahara, and to be able to optimize their production conditions.

\section{Materials and Methods}

\subsection{Materials}

The date waste were obtained from DegletNour cultivar.

\subsection{Biological strains}

2.2.1. Isolation, identification and screening of $A$. niger

Thirty strains of $A$. niger were isolated from the saline soils collected from five arid locations in Algeria. The strains were then seeded into Petri plates containing in: sucrose $30 \mathrm{~g} / \mathrm{L}, \mathrm{Na}_{2} \mathrm{NO}_{3} 2.0$ $\mathrm{g} / \mathrm{L}, \mathrm{KH}_{2} \mathrm{PO}_{4} 1.0 \mathrm{~g} / \mathrm{L}, \mathrm{MgSO}_{4} 0.5 \mathrm{~g} / \mathrm{L}, \mathrm{KCl}^{3} 0.5$ $\mathrm{g} / \mathrm{L}, \mathrm{FeSO}_{4} 0.01 \mathrm{~g} / \mathrm{L}$ and agar $20.0 \mathrm{~g} / \mathrm{L}$. After incubation at $30^{\circ} \mathrm{C}$ for 3 to 5 days, the mycelium was sub-cultured into $2 \%$ water agar for purification (17). The identification of strains of $A$. niger was based on the observations of the fungal mycelium: color and diameter of the colony, the presence of the thallus, the presence or the absence of the septum, the nature of the production and characteristics of fruiting bodies and spores (18). Finally, the strains were screened qualitatively in petri plates containing CzapekDox agar medium with Bromocresol green as an indicator (17).

\subsection{Methods}

2.3.1. Experimental protocol

2.3.1.1. Preparation of culture substrate

The preparation of the date wastes syrup was reported by Acourene and Ammouche (19).

\subsection{Inoculum preparation}

A. niger strain ANSS-B5 was inoculated in sterile $100 \mathrm{ml}$ Erlenmeyer flasks containing $20 \mathrm{ml}$ of culture medium composed by: Glucose, $20 \mathrm{~g} / \mathrm{L}$; $\left(\mathrm{NH}_{4}\right) \quad 2 \mathrm{SO}_{4}, 6.6 \mathrm{~g} / \mathrm{L} ; \mathrm{KH}_{2} \mathrm{PO}_{4}, 3.5 \mathrm{~g} / \mathrm{L}$; $\mathrm{FeSO}_{4} .7 \mathrm{H}_{2} \mathrm{O}, 0.15 \mathrm{~g} / \mathrm{L} ; \mathrm{MgSO}_{4} .7 \mathrm{H}_{2} \mathrm{O}, 0.10 \mathrm{~g} / \mathrm{L}$;
$\mathrm{MnCl}_{2} \cdot 2 \mathrm{H}_{2} \mathrm{O}, 0.45 \mathrm{~g} / \mathrm{L}$ and mycological peptone, $3.0 \mathrm{~g} / \mathrm{L}$; at $\mathrm{pH}$ 6.0. The culture was incubated at $30^{\circ} \mathrm{C}$, shaking at $220 \mathrm{rpm} / \mathrm{min}$ for $48 \mathrm{~h}$ at $\mathrm{pH} 5.0$ $(5,20)$.

\subsection{Production of $\alpha$-amylase}

The cultures were developed in $250 \mathrm{ml}$ Erlenmeyer flasks containing, $50 \mathrm{ml}$ of date waste syrup inoculated with $2 \%(\mathrm{w} / \mathrm{v})$ inoculum level of $2 \times 10^{8} \mathrm{CFU} / \mathrm{ml}$ and shaking at $200 \mathrm{rpm} / \mathrm{min}$.

\subsection{Production of invertase}

The fermentation was carried out in $250 \mathrm{ml}$ Erlenmeyer flasks containing $50 \mathrm{ml}$ of date wastes syrup inoculated with $2 \%(\mathrm{w} / \mathrm{v})$ inoculum level of $2 \times 10^{8} \mathrm{CFU} / \mathrm{ml}$ and shaking at $200 \mathrm{rpm} / \mathrm{min}$.

\subsection{Analytical Methods}

Biomass was harvested by paper filtration using a pre-dried and pre-weighted Whatman filter paper $\mathrm{N}^{\circ} 1$, washed with distilled water and dried to a constant weight at $70^{\circ} \mathrm{C} \mathrm{(5).}$

Amylase activity was assayed by adding $0.1 \mathrm{ml}$ of enzyme fermented broth supernatant to $0.2 \mathrm{ml}$ of $0.5 \%$ soluble starch and incubated for $30 \mathrm{~min}$ at $37^{\circ} \mathrm{C}$. The reaction was stopped by adding 0.4 $\mathrm{ml}$ of 3,5 dinitrosalicylic acid, followed by boiling for $10 \mathrm{~min}$. The final volume was made to $10 \mathrm{ml}$ with distilled water and the absorbency measured at $540 \mathrm{~nm}$ with U.V. spectrophotometer. A calibration curve of absorbance and concentration of Dglucose was established with a known amount of glucose (21).

Invertase activity was determined by using the method of Sumner and Howells (22) with slight modification by incubating $0.1 \mathrm{~mL}$ of the enzyme solution with $0.9 \mathrm{ml}$ of sucrose in $0.03 \mathrm{M}$ acetate buffer ( $\mathrm{pH}$ 5.0). To stop the reaction, $1 \mathrm{ml}$ of dinitrosalicylic acid reagent was added and heated for $5 \mathrm{~min}$ in a boiling water bath. The absorbance was read at $540 \mathrm{~nm}$ in U.V spectrophotometer (23).

\section{Results}

\subsection{Production of $\alpha$-amylase and invertase}

Thirty strains of $A$. niger isolated locally were tested for their potential to produce $\alpha$-amylase and invertase. While all strains in the screening experiment were able to grow on date wastes syrup and were capable of producing $\alpha$-amylase and invertase, with $A$. niger strain ANSS-B5 was 
selected as the best producer of these enzymes, thus its production conditions were optimized.

\subsection{Optimisation of $\alpha$-amylase production}

The obtained results indicate that dry biomass and $\alpha$-amylase production were $0.98 \mathrm{~g} / \mathrm{L}$ and $72.06 \mathrm{U} / \mathrm{ml}$ at $48 \mathrm{~h}$ and increased to $1.74 \mathrm{~g} / \mathrm{L}$ and $143.33 \mathrm{U} / \mathrm{ml}$ at $96 \mathrm{~h}$ (Table 1 ).

Beyond $96 \mathrm{~h}$, a decrease in $\alpha$-amylase activity, 131.07 U/mL was noted at $144 \mathrm{~h}$. To evaluate the effect of temperature on $\alpha$-amylase production the results show that the dry biomass and $\alpha$-amylase produced at $20^{\circ} \mathrm{C}$ are low, $0.78 \mathrm{~g} / \mathrm{L}$ and 100.37 $\mathrm{U} / \mathrm{mL}$, and increased to a maximum of $1.74 \mathrm{~g} / \mathrm{L}$ and $143.33 \mathrm{U} / \mathrm{mL}$, respectively at $30^{\circ} \mathrm{C}$. At higher temperatures there were gradual decreases in dry biomass and $\alpha$-amylase production, $0.42 \mathrm{~g} / \mathrm{L}$ and $24.50 \mathrm{U} / \mathrm{mL}$ when temperature was increased to $45^{\circ} \mathrm{C}$.

As shown in Figure 1, the highest levels of dry biomass and $\alpha$-amylase activity, i.e., $2.07 \mathrm{~g} / \mathrm{L}$ and $176.05 \mathrm{U} / \mathrm{ml}$ were produced at $\mathrm{pH} 5.5$, and their lowest levels, i.e., 0.96-1.18 g/L, and 95.67$126.00 \mathrm{U} / \mathrm{mL}$, were obtained at $\mathrm{pH} 4.0$ and 9.0, respectively.

On the other hand, the obtained results show that the growth and $\alpha$-amylase activity increases gradually with an increase in sugars content to reach to maximum values at $20.0 \mathrm{~g} / \mathrm{L}$ of sugars, $2.38 \mathrm{~g} / \mathrm{L}$ and $216.27 \mathrm{U} / \mathrm{mL}$, and their lowest levels, $1.65 \mathrm{~g} / \mathrm{L}$ and $107.85 \mathrm{U} / \mathrm{mL}$, were obtained at $2.5 \mathrm{~g} / \mathrm{L}$ of sugars.
Other results obtained elsewhere show that the highest dry biomass production was obtained with yeast extract, $2.96 \mathrm{~g} / \mathrm{L}$ followed by urea, $2.38 \mathrm{~g} / \mathrm{L}$, ammonium nitrate, $2.26 \mathrm{~g} / \mathrm{L}$, peptone, $2.12 \mathrm{~g} / \mathrm{L}$, meat extract, $1.88 \mathrm{~g} / \mathrm{L}$, Gunpowder milk, $1.86 \mathrm{~g} / \mathrm{L}$, Ammonium phosphate, $1.84 \mathrm{~g} / \mathrm{L}$, Ammonium sulfate, $1.79 \mathrm{~g} / \mathrm{L}$ and ammonium carbonate, $1.48 \mathrm{~g} / \mathrm{L}$. Among the organic sources, supplementation with yeast extract and urea caused an increase in $\alpha$ amylase activities, up to 256.27 and $216.26 \mathrm{U} / \mathrm{mL}$, respectively. Ammonium nitrate also enhanced the amylase activity $200.07 \mathrm{U} / \mathrm{mL}$, but ammonium carbonate showed a negative influence, showing a steep decrease in $\alpha$-amylase activity, 108.36 $\mathrm{U} / \mathrm{mL}$.

As shown, in Figure 2, the growth increased with an increase in yeast extract content to reach to a maximum value, $4.12 \mathrm{~g} / \mathrm{L}$ at $5.0 \mathrm{~g} / \mathrm{L}$.

The $\alpha$-amylase activity also reached the maximum value, $273.37 \mathrm{U} / \mathrm{mL}$ at $5.0 \mathrm{~g} / \mathrm{L}$ of yeast extract. However, beyond $5.0 \mathrm{~g} / \mathrm{L}$ yeast extract, the $\alpha$-amylase activity dropped to $216.53 \mathrm{U} / \mathrm{mL}$.

Finally, the obtained results show that the growth increased gradually with increased concentration of potassium phosphate reaching to a maximum values of $3.62-3.84 \mathrm{~g} / \mathrm{L}$ at $6.0-8.0 \mathrm{~g} / \mathrm{L}$ of potassium phosphate. The $\alpha$-amylase activity maximum values, 273.37-288.26 U/ml, were obtained with potassium phosphate content ranging between 4.0 to $8.0 \mathrm{~g} / \mathrm{L}$. The lowest growth and $\alpha$-amylase activity, $1.82 \mathrm{~g} / \mathrm{L}$ and $125.47 \mathrm{U} / \mathrm{mL}$, respectively were obtained at 2.0 $\mathrm{g} / \mathrm{L}$ of potassium phosphate content.

Table 1. Evaluation of dry biomass and $\alpha$-amylase activity following incubation period, temperature, sugars and potassium phosphate content

\begin{tabular}{|c|c|c|c|c|c|c|}
\hline \multirow{3}{*}{ Incubation period } & Time in $\mathrm{h}$ & 48 & 72 & 96 & 120 & 144 \\
\hline & Dry biomass & 0.98 & 1.12 & 1.74 & 1.94 & 2.00 \\
\hline & $\alpha$-amylase activity & 72.06 & 137.00 & 143.33 & 142.31 & 131.07 \\
\hline \multirow{3}{*}{ Temperature } & ${ }^{\circ} \mathrm{C}$ & 20 & 30 & 35 & 40 & 45 \\
\hline & Dry biomass & 0.78 & 1.74 & 1.36 & 0.74 & 0.42 \\
\hline & $\alpha$-amylase activity & 100.36 & 143.33 & 111.53 & 80.00 & 24.50 \\
\hline \multirow{3}{*}{ Sugars } & Content in $\mathrm{g} / \mathrm{L}$ & 2.5 & 5 & 10 & 15 & 20 \\
\hline & Dry biomass & 1.65 & 1.74 & 1.98 & 2.07 & 2.38 \\
\hline & $\alpha$-amylase activity & 107.85 & 129.80 & 161.23 & 176.05 & 216.27 \\
\hline \multirow{3}{*}{$\begin{array}{l}\text { Potassium phos- } \\
\text { phate }\end{array}$} & Content in $\mathrm{g} / \mathrm{L}$ & 2.0 & 4.0 & 5.0 & 6.0 & 8.0 \\
\hline & Dry biomass & 1.82 & 3.29 & 3.36 & 3.62 & 3.84 \\
\hline & $\alpha$-amylase activity & 125.47 & 273.37 & 285.60 & 288.26 & 287.80 \\
\hline
\end{tabular}




\subsection{Optimisation of invertase production}

The results obtained show that the growth and invertase production were $2.60 \mathrm{~g} / \mathrm{L}$ and 25.62 $\mathrm{U} / \mathrm{mL}$ at $48 \mathrm{~h}$ and increased up to $3.60 \mathrm{~g} / \mathrm{L}$ and $124.32 \mathrm{U} / \mathrm{mL}$ at $96 \mathrm{~h}$ (Table 2).

Interestingly, after 96 to $144 \mathrm{~h}$, growth increased slightly, $5.26 \mathrm{~g} / \mathrm{L}$ at $144 \mathrm{~h}$, but a lower invertase activity was observed, 109.88 and 97.66 $\mathrm{U} / \mathrm{ml}$ at $120 \mathrm{~h}$ and $144 \mathrm{~h}$, respectively. Temperature was varied to evaluate its effect on invertase production. The results show that the maximum growth and invertase activity, i.e., $3.60 \mathrm{~g} / \mathrm{L}$ and 124.32 U/mL, were obtained at $30^{\circ} \mathrm{C}$. Further increase in temperature declines the growth and invertase production, 1.82 to $2.54 \mathrm{~g} / \mathrm{L}$, and 32.34 to $65.61 \mathrm{U} / \mathrm{mL}$ at temperatures of 45 and $40^{\circ} \mathrm{C}$, respectively.

As shown in Figure 3, the growth and invertase activity were at maximum at initial $\mathrm{pH} 5.0$ and $\mathrm{pH}$ 6.0, 3.60-3.75 g/L and 124.32 - $133.59 \mathrm{U} / \mathrm{mL}$, respectively. The lowest invertase activity, 93.58 $\mathrm{U} / \mathrm{mL}$ was obtained at $\mathrm{pH} 3.0$. At $\mathrm{pH} 7.0$, dry biomass and invertase production declined, i.e., 2.40 $\mathrm{g} / \mathrm{L}$ and $111.14 \mathrm{U} / \mathrm{mL}$, respectively.

The results obtained show that the growth and invertase activity increased gradually with sugars content to reach to maximum values of 3.95-4.76 $\mathrm{g} / \mathrm{L}$ and $170.10-171.20 \mathrm{U} / \mathrm{mL}$, respectively at 40.0 $-50.0 \mathrm{~g} / \mathrm{L}$ of sugars content. The lowest values, $2.40 \mathrm{~g} / \mathrm{L}$ and $27.32 \mathrm{U} / \mathrm{mL}$, respectively were obtained at $10.0 \mathrm{~g} / \mathrm{L}$ of sugars.

Yeast extract content was varied to evaluate the effect on invertase production. As shown in Figure

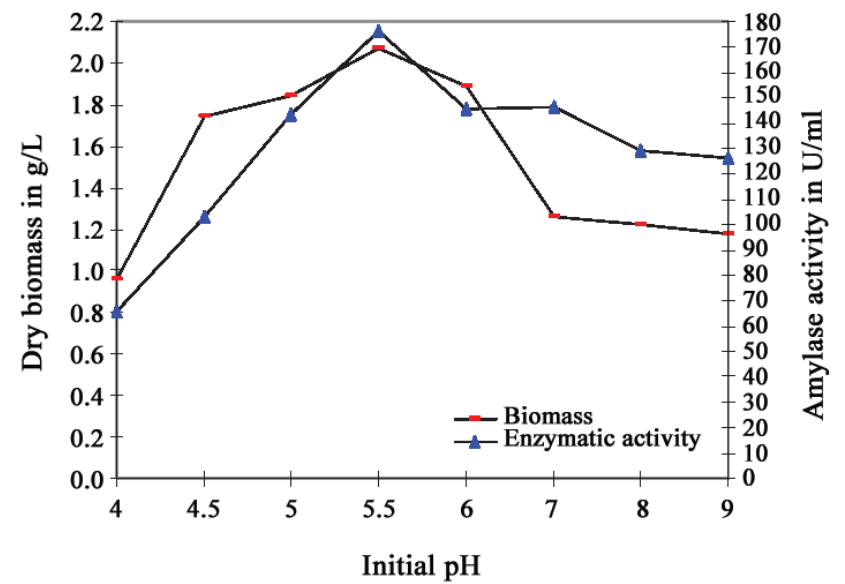

Figure 1. Evaluation of dry biomass and $\alpha$-amylase activity following initial $\mathrm{pH}$ after $96 \mathrm{~h}$ of incubation, temperature of $30^{\circ} \mathrm{C}$, sugars content of $15 \mathrm{~g} / \mathrm{L}$, urea as a source of nitrogen at $4.0 \mathrm{~g} / \mathrm{L}$ and potassium phosphate content of $4.0 \mathrm{~g} / \mathrm{L}$
4, the higher invertase production, $195.56 \mathrm{U} / \mathrm{ml}$ was obtained at $11.0 \mathrm{~g} / \mathrm{L}$ of yeast extract content and the dry biomass was $4.22 \mathrm{~g} / \mathrm{L}$.

The lowest values, 0.20 to $2.80 \mathrm{~g} / \mathrm{L}$ and 0 to $62.33 \mathrm{U} / \mathrm{mL}$ were obtained at yeast extract contents $\leq 6.0 \mathrm{~g} / \mathrm{L}$. At higher yeast extract contents $\geq$ $12.0 \mathrm{~g} / \mathrm{L}$, a decrease in invertase production, $163.59 \mathrm{U} / \mathrm{ml}$ but an improvement of growth, 5.20 $\mathrm{g} / \mathrm{L}$, were noted.

The effect of potassium phosphate content on invertase production was measured.

The results show that the addition of potassium phosphate to the culture medium improved the growth of $A$. niger and the maximum dry biomass, $4.65 \mathrm{~g} / \mathrm{L}$ at $4.0 \mathrm{~g} / \mathrm{L}$ of potassium phosphate. Whereas, the maximum invertase production, $195.56 \mathrm{U} / \mathrm{mL}$ was obtained at $3.5 \mathrm{~g} / \mathrm{L}$. Any decrease in the phosphate concentration beyond optimum, greatly reduced the invertase activity due to improper growth of $A$. niger ANSS-B5, thus the lowest growth and invertase activity, 2.10 $\mathrm{g} / \mathrm{L}$ and $60.15 \mathrm{U} / \mathrm{mL}$, respectively were obtained at $1.0 \mathrm{~g} / \mathrm{L}$ of potassium phosphate content.

\section{Discussion}

\subsection{Optimization of $\alpha$-amylase production}

The incubation time for achieving maximum enzyme level is governed by the characteristics of the culture. So, the optimum fermentation period for maximum $\alpha$-amylase production was $96 \mathrm{~h}$. On further incubation, the enzyme activity gradually decreased. This may be due to the depletion of

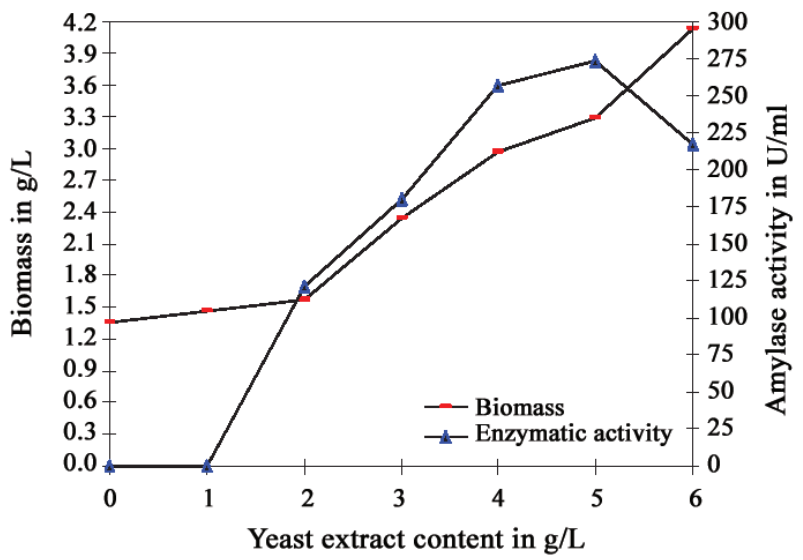

Figure 2. Evaluation of dry biomass and $\alpha$-amylase activity following yeast extract content after $96 \mathrm{~h}$ of incubation, temperature of $30^{\circ} \mathrm{C}$, initial $\mathrm{pH} 5.5$ and potassium phosphate content of $4.0 \mathrm{~g} / \mathrm{L}$. 
Table 2. Evaluation of dry biomass and invertase activity following incubation period, temperature, sugars and potassium phosphate content

\begin{tabular}{llccccc}
\hline \multirow{4}{*}{ Incubation period } & Time in $\mathrm{h}$ & 48 & 72 & 96 & 120 & 144 \\
& Dry biomass & 2.60 & 3.20 & 3.60 & 4.80 & 5.26 \\
& Invertase activity & 25.62 & 68.80 & 124.32 & 109.88 & 97.66 \\
\multirow{5}{*}{ Temperature } & ${ }^{\circ} \mathrm{C}$ & 20 & 30 & 35 & 40 & 45 \\
& Dry biomass & 2.73 & 3.60 & 2.84 & 2.54 & 1.82 \\
\multirow{5}{*}{ Sugars } & Invertase activity & 92.54 & 124.32 & 91.22 & 65.61 & 32.34 \\
& Content in g/L & 10 & 20 & 30 & 40 & 50 \\
\multirow{2}{*}{ Potassium phos- } & Dry biomass & 2.40 & 3.00 & 3.75 & 3.95 & 4.76 \\
phate & Invertase activity & 27.32 & 103.2 & 133.59 & 170.12 & 171.20 \\
\hline
\end{tabular}

essential nutrients required for the growth and enzyme production. Similar results were reported by Djekrif-Dakhmouche et al., (3); GuillenMoreira et al., (4); Wang et al. (24). In contrast, Bhadwaj et al., (25); Farid and Shata (26); Suganthi et al., (27) have obtained higher $\alpha$-amylase activity at 120 to $144 \mathrm{~h}$ with strains of $A$. flavus, A. oryzae LS1, A. oryzae NRRL 6586 and A. niger BAN-3E.

Temperature is one of the important factors, which strongly affects the submerged fermentation (4). The optimum temperature for maximum $\alpha$-amylase activity was $30^{\circ} \mathrm{C}$, and DjekrifDakhmouche et al. (3); Ramachandran et al. (6); Acourene and Ammouche (19); Wang et al. (24);

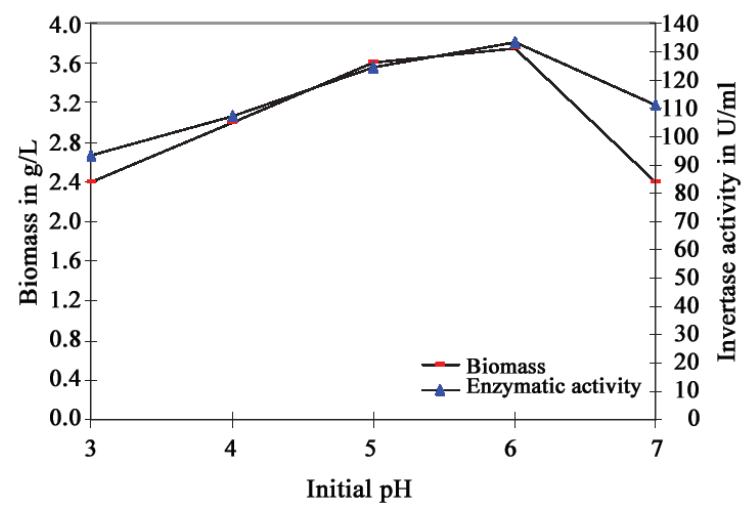

Figure 3. Evaluation of dry biomass and invertase activity following initial $\mathrm{pH}$ after $96 \mathrm{~h}$ of incubation, temperature of $30^{\circ} \mathrm{C}$, sugars content of $30.0 \mathrm{~g} / \mathrm{L}$, yeast extract content of $10.0 \mathrm{~g} / \mathrm{L}$ and potassium phosphate content of $3.0 \mathrm{~g} / \mathrm{L}$
Bhardwaj et al. (25); Alva et al. (28); Gupta et al. (29); Jin et al. (30); Renato et al. (31); Reazaei et al. (32) have also reported similar results. A further increase in temperature resulted in a decrease in $\alpha$-amylase activity. At temperature above $45^{\circ} \mathrm{C}$ resulted in moisture loss of the substrate, which affects metabolic activities of the micro-organism and resulted in reduced growth and $\alpha$-amylase production (7). In contrast, Ray et al. (33) reported that the optimum temperature for maximum $\alpha$ amylase production by $B$. brevis is $50^{\circ} \mathrm{C}$.

Among the physicals parameters, the $\mathrm{pH}$ of medium plays an important role by inducing morphological changes in the organism and in enzyme secretion (29). The production of $\alpha$-amylase is

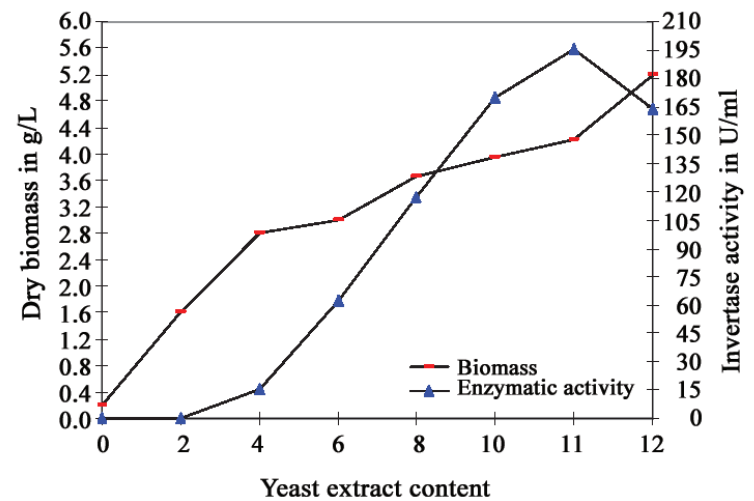

Figure 4. Evaluation of dry biomass and invertase activity following yeast extract content after $96 \mathrm{~h}$ of incubation, temperature of $30^{\circ} \mathrm{C}$, initial $\mathrm{pH} 6.0$, sugars content of 40.0 $\mathrm{g} / \mathrm{L}$ and potassium phosphate content of $3.0 \mathrm{~g} / \mathrm{L}$ 
very sensitive to initial $\mathrm{pH}$ of the medium. Our findings are comparable to previously reported results from literature that reported maximum $\alpha$ amylase production at a $\mathrm{pH}$ varying between 5.0 and $6.0(3,7,19,25,28-30,32)$. According to Varalakhshmi et al., (34), the amylases production by $A$. flavus and $A$. niger JGI 24 were found maximum at $\mathrm{pH} 7.0$ to 7.5 .

In contrast, Gangadharan et al., (35) reported that $\mathrm{pH} 3.5$ to be the best for the production of áamylase. According to Guillen-Moreira et al., (4); Gupta et al., (29), the growth and enzyme production were inhibited when the initial $\mathrm{pH}$ of the medium was above 10.0 or below 4.0.

Sugar content is a crucial factor in submerged fermentation and its importance for $\alpha$-amylase production has been well established. The optimum sugars content for maximum yield was 20.0 $\mathrm{g} / \mathrm{L}$. Similar results were obtained by Hernandez et al., (5) and Acourene and Ammouche (19) with strains of $C$. guilliermondii CGL-A10 and $A$. niger.

Studies on supplementation of inorganic and organic nitrogen sources to the date wastes syrup showed a mixed trend on enzyme production. Added nitrogen sources have been reported to have an inducing effect on the production of various enzymes including $\alpha$-amylase (36). This study shows that the yeast extract is the best nitrogen source. Similar results were reported by Hernandez et al., (5); Bhardwaj et al., (25); Anto et al., (37) with $A$. niger and A. flavus. According to Ray et al., (33); Varalakshmi et al., (34), B. brevis and $A$. niger JGI 24 produced more amylase in the presence of meat extract or beef extract as nitrogen source.

In contrast, Hernandez et al., (25); Gupta et al. (29) showed that the peptone was the best nitrogen source. Finally, Radha-Krishna et al., (38) obtained high amylase activity when ammonium nitrate was used.

On the other hand, the optimum yeast extract content for maximum $\alpha$-amylase production was $5.0 \mathrm{~g} / \mathrm{L}$. Similarly, Guillen-Moreira et al. (4) obtained at a organic nitrogen source of $5.0 \mathrm{~g} / \mathrm{L}$. Moreover, the maximum gluco-amylase produced was obtained with a concentrations of yeast extract ranging between 3.0 and $5.0 \mathrm{~g} / \mathrm{L}$ (39), whereas Rezaei et al., (32) obtained high $\alpha$-amylase activity with $A$. niger at $2.0 \mathrm{~g} / \mathrm{L}$ the organic nitrogen source. In contrast, Radha-Krishna et al.,
(38) obtained a maximum $\alpha$-amylase activity at $10.0 \mathrm{~g} / \mathrm{L}$ of ammonium nitrate as inorganic nitrogen source with $A$. niger.

Phosphate serves as the construction material of cellular components such as cyclic AMP, nucleic acids, phospholipids, nucleotides and coenzymes (35). The optimum phosphate content for maximum growth and $\alpha$-amylase production was $5.0 \mathrm{~g} / \mathrm{L}$. Similar results were recorded by Acourene and Ammouche (19); Gangadharan et al. (35) with C. guilliermondii and B. amyloliquefaciens.

Moreover, Zaldivar-Aguero et al., (40) reported that the synthesis of $\alpha$-amylase is stimulated by adding 7.0 to $10.0 \mathrm{~g} / \mathrm{L}$ phosphorus to the culture medium. In contrast, Jin et al., (30) did not obtain a significant improvement in gluco-amylase yields by adding phosphorus to the fermentation medium.

\subsection{Optimization of invertase production}

The incubation period is governed by the characteristics of the culture and is based on the growth rate and enzyme production. In this study, the optimum incubation period for maximum invertase production was $96 \mathrm{~h}$. A similar result was found by Ashokumar et al. (10); Cheng and Liu (12); Guimaraes et al. (13); Uma et al. (16); Praveen-Reedy et al., (41); Uma et al., (42) with A. niger, A.japonicas, $A$. ochraceus, A. fumigatus and $A$. flavus. Further increase in the incubation time caused a slow decrease in invertase activity. Similar results were reported by Praveen-Reedy et al., (41) and Gomez et al., (43).

The optimum temperature in the present study for maximum growth and biosynthesis of invertase was $30^{\circ} \mathrm{C}$. Further increase in temperature caused a decline in the invertase production. Similar findings were recorted by Uma et al. (16); Praveen-Reedy et al. (41); Uma et al. (42); Alegre et al. (44); Rajoka and Yasmeen (45) with strains of $A$. caespitosus, A. niger, A. fumigatus and $A$. flavus. In contrast, Viana et al., (46) obtained high invertase activity at temperature of $40^{\circ} \mathrm{C}$ with strain of $A$. sp GH1.

Optimal pH is very important for growth of micro-organisms and their metabolic activities. In our system, an initial pH 6.0 was regarded as optimal for invertase production. A similar result was reported by Hayashi et al., (8); Cheng and Liu (12); Praveen-Reedy et al., (41); Alegre et al., 
(44); Rajoka and Yasmeen (45); Shankar et al. (47); Sirisansaneeyakul et al., (48) with strains of A. caespitosus, A. japonicus and $A$. niger. In contrast, Guimaraes et al., (13); Praveen-Reedy et al., (41); Viana et al., (46) obtained maximum invertase production with an initial $\mathrm{pH}$ ranging between 3.5 to 4.5 with strains of $A$. ochraceus, $A$. niger and Fusarium sp.

Sugars content influenced strongly the level of invertase production. We found the optimum sugars content for maximum invertase activity to be $40.0 \mathrm{~g} / \mathrm{L}$. This optimum was similar to the level reported by Ashokumar et al., (10) with A. niger. In contrast, Uma et al., (42) obtained maximum invertase production at $10.0 \mathrm{~g} / \mathrm{L}$ of sugars content with A. fumigatus.

Nitrogen constituent has a profound effect on invertase production because there exists a strong correlation between nitrogen equilibrium and the productivity of microorganisms (14). We report the optimal yeast extract content for maximum invertase production is $11.0 \mathrm{~g} / \mathrm{L}$. A similar result was reported by Hayashi et al., (8). In contrast, Cheng and Liu (12) obtained a maximum invertase activity at $26.0 \mathrm{~g} / \mathrm{L}$ of yeast extract with $A$. japonicus.

Phosphate source plays a key role in enhancing invertase secretion (43). The optimum potassium phosphate content for maximum invertase production was $3.5 \mathrm{~g} / \mathrm{L}$. Similar findings have previously been reported by Alegre et al., (44) with A. caespitosus. In contrast, according to Cheng and Liu (12), the addition of potassium phosphate shifted the morphology of the fungal growth from filamentous to pellet form, but this salt did not affect invertase production with $A$. japonicus.

\section{Conclusions}

$\alpha$-Amylase and invertase are industrially important enzymes and their demand is increasing in line with the growing global markets for processed food, especially the confectionery industry. The use of $\alpha$-amylase and invertase are somewhat limited due to its high price. Thus the optimization of the production process is very important, so as to make it more economical and feasible. The present study contributed toward to the optimization of nutritional parameters and cultural conditions.

The growth and $\alpha$-amylase or invertase production with $A$. niger ANSS-B5 were influenced by various nutritional and environmental factors. The obtained results show that the composition of the medium is a major factor in regulating of the synthesis of $\alpha$-amylase and invertase.

It is concluded from these results that $A$. niger ANSS-B5 isolated from saline soil of Algerian aridic regions when cultured in submerged fermentation using date wastes product as carbon source is very interesting for industrial scale applications in the production of $\alpha$-amylase and invertase.

\section{Acknowledgements}

Acourene Said is thankful to the Algerian National Institute of Agricultural Research for financial assistance during this work.

\section{References}

1. Anonymous. Date palm, Areas and productions. In: Agricultural statistics, Series B, Agricultural Statistics Direction of the Algerian Agricultural Ministry (ASDAAM) ed., Alger. 2011;PP. 50-55.

2. Pandey A, Nigam P, Soccol C R, Soccol VT, Singh D, Mohan R. Advances in microbial amylases, Biotechnol Appl Biochem. 2000;31:135152.PMID:10744959[PubMed - indexed for MEDLINE]

3. Djekrif-Dakhmouche S, Gheribi-Aoulmi Z, Meraihi Z, Bennamoun L. Application of a statistical design to the optimization of culture medium for amylase production by Aspergillus niger ATCC 16404 grown on orange waste powder. Food Eng. 2006;73:190197.doi:10.1016/j.jfoodeng.2005.01.021

4. Guillen-Moreira F, Arrias de Lima F, Fazzano Pedrinho SR, Lenartovicz C, Giatti Marques de Souza RM, Peralta C. Production of amylases by Aspergillus tamari. Revista Microbiologica. 1999;30(2):1-9.

5. Hernandez MS, Rodrýguez MR, Perez-Guerra N, PerezRoses R. Amylase production by Aspergillus niger in submerged cultivation on two wastes from food industries. J Food Eng. 2006;73: 93-100.doi:10.1016/j.jfoodeng.2005.01.009

6. Ramachandran S, Patel AK, Nampoothiri KM, Chandran S, Szakacs G, Soccol CR, Pandey A. Alpha amylase from a fungal culture grown on oil cakes and its properties. Brazilian Archiv Biol Technol. 2004;47:309-317.

7. Sindhu R, Suprabha GN, Shashidhar S. Optimization of process parameters for the production of $\alpha$-amylase from Penicillium janthinellum (NCIM 4960) under solid state fermentation. African J Microbiol Res. 2009;3(9):498-503.

8. Hayashi A, Matsuzaki Y, Takasaki Ueno H, Imada K. Production of $\beta$-fructofuranosidase by Aspergillus japonicus. World J Microbiol Biotechnol. 1992;8:155159.doi:10.1007/BF01195837

9. Aranda C, Robledo A, Loera O, Contreras-Esquivel JC, 
Rodriuez R, Aguilar N. Fungal invertase expression in solid state fermentation. Food Technol Biotechnol. 2006;44(2):229-233.

10. Ashokkumar B, Kayalvizhi N, Gunasekaran P. Optimization of media for $\beta$-fructofuranosidase production by Aspergillus niger in submerged and solid state fermentation. Process Biochem. 2001;37(4): 331338.

11. Bousmaha L, El-Moualidi L, Oouhssine M, El-Yachioui M. Souches de Candda guilliemondii isolées de la saumure de carottes productrices d'une $\beta$ Fructofuranosidase extracellulaire. Bulletin Societé Pharmacie. 2007;146:51-62.

12. Cheng WC, Liu C. Production of $\beta$-fructofuranosidase by Aspergillus japonicus. Enzyme Microb Technol. 1996;18(2): 153 - 160 .doi:10.1016/0141 0229(95)00099-2

13. Guimaraes LHS, Terenzi HF, Polizeli ML, Jorge JA. Production and characterization of a thermostable extracellular $\beta$-D-fructofuranosidase produced by Aspergillus ochraceus with agro industrial residues as carbon sources. Enzyme Microb Technol. 2007;42:5257.doi:10.1016/j.enzmictec.2007.07.021

14. Ikram UH, Mirza AB, Sikander A. Effect of cultivation conditions on invertase production by hyperproducing Saccharomyces cerevisiae isolates. World J Microbiol Biotechnol.2005;21:487492.doi:10.1016/j.enzmictec.2007.07.021

15. Kotywal SM, Shankar V. Immobilised invertase. Rev Biotechnol Adv. 2009;27:311-322.doi:10.1007/s11274004-2612-7

16. Uma C, Gomathi D, Muthulakshmi C, Gopalakrishnan VK. Production, Purification and characterization of invertase by Aspergillus flavususing fruit peel waste as substrate. Adv Biol Res. 2010a;4(1):31-36.

17. Botton B, Bretton A, Fever M, Gautier S, Guy PH, Larpent JP, Reymond P, Sanglier JJ, Vayssier Y, Veau P. Moisissures utiles et nuisibles, importance industrielle. Masson, Paris; 1990.

18. Hawksworth DL, Kirk PM, Sutton B, Pegler DN. Ainsworth and Bisby's Dictionary of the Fungi. Commonwealth Mycological Institute, CABI publishing, London; 1995.

19. Acourene S, Ammouche A. Optimization of ethanol, citric acid, and $\alpha$-amylase production from date wastes by strains of Saccharomyces cerevisiae, Aspergillus niger, and Candida guilliermondii. $J$ Ind Microbiol Biotechnol. 2012;39(5):759-766.doi:10.1007/s10295011-1070-0

20. Romero-Gomez S, Augur C, Viniegre-Gonzalez G. Invertase production by Aspergillus niger in submerged and solid-state fermentation. Biotechnol Letters. 2000;22:1255-1258.

21. Bernfeld P. Amylase, $\alpha / \beta$. In: Methods in Enzymology, Academic Press ed., New-York. 1955;PP. 149-154.

22. Sumner JB, Howell SF. A method for determination of saccharase activity. J Biol Chem. 1935;108:51-54.

23. Miller GL. Use of dinitrosalicylic acid reagent for deter- mination of reducing sugar. Anal Chem. 1959;31:426428.

24. Wang Q, Wang X, Maa H. Glucoamylase production from food wastes by Aspergillus niger under submerged fermentation. Process Biochem. 2008;43:280286.doi:10.1016/j.procbio.2007.12.010

25. Bhardwaj S, Bhattacharya S, Anand S, Das A. Production and characterization of amylase from a mangrove isolate of Aspergillus flavus using sugar cane bagasse in solid state fermentation. American Euras $J$ Agr Environ Sci. 2011;3(4):171-181.

26. Farid MAF, Shata HAH. Amylase production from Aspergillus oryzae LS1 by solid-state fermentation and its use for the hydrolysis of wheat flour. Iranian $J$ Biotechnol. 2011;9(4):267-274.

27. Suganthi R, Benazir JF, Santhi R, Ramesh K, Hari A, Meenakhi N, Nidhiya KA, Kavitha G, Lakshmi R. Amylase production by Aspergillus niger under solid state fermentation using Agro- industrial wastes. Int $J$ Eng Sci Technol. 2011;3(2):1756 1763.

28. Alva S, Anupama J, Savla J, Chiu YY, Vyshali P, Shruti M, Yogeetha BS, Bhavya D, Purvi J, Ruchi K, Kumudini, BS, Varalakshmi KN. Production and characterization of fungal amylase enzyme isolated from Aspergillus sp. JGI 12 in solid state culture. African $J$ Biotechnol. 2007;6(5):576-581.

29. Gupta A, Gautam N, Modi, DR. Optimization of amylase production from free and immobilized cells of Aspergillus niger. $J$ Biotechnol Pharm Res. 2010;1(1):1-8.

30. Jin B, Van-Leeuan HJ., Patel B, Yu Q. Utilization of starch processing wastewater for production of microbial biomass protein and fugal $\alpha$-amylase by Aspergillus oryzae. Bioresour Technol. 1998;66:201206.doi:10.1016/S0960-8524(98)00060-1

31. Renato PR, Nelson PG. Optimization of amylase production by Aspergillus niger in solid-state fermentation using sugarcane bagasse as solid support material. World J Microbiol Biotechnol. 2009;25(11):9291939.doi:10.1007/s11274-009-0091-6

32. Rezaei PS, Darzit GN, Shafaghat H. Optimization of the fermentation conditions and partial characterization for acido-thermophilic $\alpha$-amylase from Aspergillus niger NCIM 548. Korean J Chem Eng. 2010;27(3):919924.doi:10.1007/s11814-010-0138-2

33. Ray RC, Kar S, Nayak S, Swain MR. Extracellular $\alpha$-amylase production by Bacillus brevis MTCC 7521. Food Biotechnol. 2008;22:234-246.doi:10.1080/08905430802262558

34. Varalakshmi KN, Kumudini BS, Nandini BN, Solomon J, Suhas R, Mahesh B, Kavitha AP. Production and characterization of $\alpha$-amylase from Aspergillus niger JGI 24 isolated in Bengalore. Polish $J$ Microbiol. 2009;58(1):29-36.

35. Gangadharan D, Sivaramakrishnan S, Nampoothiri KM, Pandey A. Solid culturing of Bacillus amyloliquefaciens for $\alpha$-amylase production. Food Technol Biotechnol. 2006;44(2):269-274. 
36. Kaur P, Grewal HS, Kocher GS. Production of $\alpha$-amylase by Aspergillus niger using wheat bran in submerged and solid state fermentations. Indian $J$ Microbiol. 2003;43:143-145.

37. Anto H, Trivedi UB, Patel KC. Glucoamylase production by solid-state fermentation using rice flake manufacturing waste products as substrate. Bioresour Technol. 2006;97(10):11611166.doi:10.1016/j.biortech.2005.05.007

38. Radha-Krishna P, Srivastava AK, Ramaswamy NK, Suprasanna SF, D'Souza P. Banana peel as substrate for $\alpha$-amylase production using Aspergillus niger NCIM 616 and process optimization. Indian J Biotechnol. 2012;11:314-319.

39. Kunameni A, Permaul K, Singh S. Amylase production in solid-state fermentation by the thermophilic fungus Thermomyces lanuginosus. J Biosci Bioeng, 2005;100: 168-171.doi:10.1263/jbb.100.168

40. Zaldivar-Aguero JM, Badino AC, Vilaça PR, Facciotti MCR. Schmide W. Influence of phosphate concentration on gluco-amylase production by Aspergillus awamori in submerged culture. Brazilian J Chem Eng. 1997;14:104-108.

41. Praveen-Reddy P, Reddy GSN, Sulochana MB. Highly thermostable $\beta$-fructofuranosidase from Aspergillus niger PSSF21 and its application in the synthesis of fructooligosacharides from agro industrial residue. Asian J Biotechnol. 2010;2:8698.doi:10.3923/ajbkr.2010.86.98

42. Uma C, Gomathi D, Muthulakshmi C, Gopalakrishnan VK. Optimization and characterization of invertase by
Aspergillus fumigatus using fruit peel waste as substrate. Res J Pharm Biol Chem Sci. 2010b;1(2):93-101.

43. Gomez SJR, Augur C, Viniegre-Gonzalez G. Invertase production by Aspergillus niger in submerged and solid-state fermentation. Biotech Letters. 2000;22: 1255-1258.

44. Alegre ACP, Teixeira de Moraes-Polizeli, ML, Terenzi HF, Jorge JA, Souza-Guimaraes LH. Production of thermostable invertase by Aspergillus caespitosus under submerged or solid state fermentation using agroindustrial residues as carbonate source. Brazilian $J$ Microbiol. 2009;40: 612-622.

45. Rajoka MI, Yasmeen A. Improved productivity of $\beta$ fructofuranosidase by a depressed mutant of Aspergillus niger from conventional and non-conventional substrates. World J Microbiol Biotechnol. 2005;21(4):471-478.doi:10.1007/s11274-004-1995-9

46. Veana F, Aguilar CN, Rodríguez Herrera R. Kinetic studies of invertase production by xerophilic Aspergillus and Penicillium strains under submerged cultures. Micologia Aplicada Int. 2011;23(2):37-45.

47. Shankar S, Madhan R, Sathyvani R, Niket B. Production and partial purification of invertase using Cympopogan caecius leaf powder as substrate. Indian Microbiol. 2010;50(3):318-324.doi:10.1007/s12088-010-0011-3

48. Sirisansaneeyakul S, Jitbanjongkit S, Prasomsart N, Luangpituksa P. Production of $\beta$-fructofuranosidase from Aspergillus niger ATCC20611. kasestart $J$ Nat Sci. 2000;34:378-386. 